\title{
MULTIKULTURALISME DALAM PERSPEKTIF BUDAYA PESISIR
}

\author{
* Singgih Tri Sulistiyono
}

\begin{abstract}
Abstrak
Paradigma multikulturalisme yang menekankan sikap dialog, toleransi, dan kesediaan untuk koeksistensi damai dalam keberagaman sesui dengan salah satu pilar kebangsaan Indonesia, yaitu Bhinneka Tungal Ika. Hal itu sesuai dengan relitas bangsa Indonesia yang bersifat plural sehingga membutuhkan paradigma yang mampu membingkai keberagaman. Masyarakat dan peradaban pesisir memiliki perspektif multikulturalisme yang berakar dari latar belakang historisnya. Perspektif multikulturalisme peradaban pesisir dapat dilihat dari sifat kosmopolitanitas dan pluralitas masyarakat dan budayanya. Masyarakat pesisir sejak lama telah memiliki jaringan nteraksi global yang sangat luas memlaui berbagai media seperti pelayaran, perdagangan, migrasi, dan sebagainya. Masyarakat dan budaya pesisir merupakan bagian yang inheren dari budaya dunia. Sifat kosmopolitanitas ini yang menyebabkan peradaban pesisir ini memiliki sifat terbuka, demokratis, toleran, dialog, kemauan unutk berkoeksistensi damai. Sementara itu sifat pluralitas masyarakat dan budaya pesisir juga tidak dapat dilepaskan dari akan historis. Sejak zaman kuno masyarakat pesisir merupakan masyarakat yang plural sebagai akibat dari kegiatan pelayaran, perdagangan, hubungan-hubungan politik dan budaya, diaspora, dan sebagainya. Hal ini mengondisikan masyarakat pesisir sebagai masyarakat plural. Pengalaman hidup bersama dalam perbedaan namun memiliki kepentingan yang sama telah melahirkan mentalitas multikulturalisme yang merupakan ciri inheren peradaban pesisir. Peradaban pesisir merupakan peradaban yang dinamis dan selalu terbuka bagi perubahan. Dalam perjalanan sejarah selalu terjadi proses pembentukan dan pembentukan kembali identitas masyarakatyang bergantung kepada dinamika internal dan pengaruh eksternal.
\end{abstract}

\section{Kata Kunci: multikulturalisme, budaya pesisir}

\section{Pendahuluan}

Dengan menggunakan pendekatan historis, makalah ini mencoba untuk mengungkap fenomena multikulturalisme dalam budaya pesisir. Seperti diketahui bahwa selama beberapa dekade terakhir ini, multikulturalisme menjadi bahan diskusi yang sangat hangat di kalangan ilmuwan sosial, budaya, politik, LSM (Lembaga swadaya Masyarakat), pejabat pemerintah, dan bahkan di kalangan tertentu dalam masyarakat. Kehangatan diskusi mengenai multikulturalisme ini tidak dapat dilepaskan dari kecenderungan global yang semakin mengakui keberagaman (pluralitas) namun dalam bingkaian suasana saling mengakui dan menghargai serta kesediaan untuk dapat hidup berdampingan dalam koeksistensi damai. Dalam hubungan ini, secara umum multikulturalisme sering dimaknai sebagai sebuah paham yang menekankan tentang penerimaan terhadap realitas keragaman, dan berbagai macam budaya (multikultural) yang ada dalam kehidupan masyarakat menyangkut nilainilai, sistem, budaya, kebiasaan, dan politik

* Singgih Tri Sulistiyono adalah Ketua DPW LDII Provisnsi Jawa Tengah, Dosen Jurusan Sejarah Fakultas Ilmu Budaya Universitas Diponegoro Semarang 
yang mereka anut. Oleh karena itu dialog dan toleransi merupakan sesuatu yang esensial dalam paham multikulturalisme. ${ }^{1}$ Konsep multikulturalisme dibedakan dengan pluralisme yang lebih mengacu hanya kepada fenomena pluralitas atau keberagaman tanpa mempersoalkan semangat saling mengakui, toleransi, dan koeksistensi damai.

Di Indonesia sendiri terdapat kecenderungan untuk memperlakukan konsep multikulturalisme tidak hanya sekedar menjadi bahan kajian ilmiah, tetapi hampir-hampir menjadi semacam ideologi yang hendak diimplementasikan dalam kehidupan masyarakat. Hal ini bukan merupakan sesuatu yang aneh mengingat secara sosiologis dan kultural, masyarakat Indonesia merupakan masyarakat plural yang memiliki potensi yang sangat besar bagi munculnya konflik dan perpecahan jika tidak disemangati oleh multikulturalisme. Bahkan konsep ini bisa diserupakan dengan konsep 'bhinneka tunggal ika'. Meskipun masyarakat Indonesia merupakan masyarakat yang pluralistik dari sisi ras, etnik, status, kepercayaan, dan sebagainya,

*Naskah ini pernah dipresentasikan pada Seminar Nasional "Multikulturalisme dan Integrasi Bangsa dalam Pembangunan Kebudayaan dan Pariwisata" yang diselenggarakan oleh Kementerian Kebudayaan dan Pariwisata (Semarang: 7 Juli 2011).

* Dosen Jurusan Sejarah Fakultas Ilmu Budaya, Universitas Diponegoro. Ketua Masyarakat Sejarawan Indonesia Cabang Jawa Tengah.

1 Lihat misalnya H.A.R. Tilaar, Multikulturalisme: Tantangan-tantangan Global Masa Depan dalam Transformasi Pendidikan Nasional (Jakarta: Grasindo, 2004). namun merupakan suatu kesatuan guna mencapai tujuan bersama dalam konteks NKRI (Negara Kesatuan Republik Indonesia) yang berdasarkan Pancasila dan UUD 1945. Namun demikian semangat 'bhinneka tunggal ika' dan multikulturalisme ini bisa merupakan state of the art dan sebuah imagined condition. Sebagai state of the art konsep ini mengaju kepada kondisi riil di dalam masyarakat Indonesia yang pluralistik dan masih jauh dari keyakinan multikulturalisme terbukti dengan masih maraknya kekerasan antar elemen di dalam masyarakat. Semagai imagined condition, multikulturalisme ataupun 'bhinneka tunggal ika-isme' merupakan sebuah citacitayang diiealisasikan yang tentu saja membutuhkan proses yang panjang yang terus-menerus perlu perbaikan yang berkesinambungan

(continual improvement).

Oleh karena latar belakang perkembangan historis yang berbeda-beda antara satu kelmpok sosial dengan kompok sosial yang lain di Indonesia, maka mereka juga memiliki tingkat multikulturalitas yang berbeda-beda. Hal itu ditentukan baik oleh karakteristik kondisi alamiah maupun aspek-aspek lain yang terkait seperti ekonomi, politik, sosial, budaya, dan sebagainya. Dalam sejarah Indonesia, orang biasanya membedakan adanya dua tipe utama masyarakat dan budaya, yaitu masyarakat agraris atau pedalaman dan 
masyarakat pesisir. ${ }^{2}$ Dalam banyak literatur disampaikan bahwa masyarakat dan budaya pesisir lebih memiliki karakteristik yang multikulturalistik daripada masyarakat pedalaman. Dalam hubungan itu, makalah ini mencoba unutk menyoroti beberapa hal, yaitu mengenai pemahaman tentang budaya pesisir dan multikulturalisme dalam perspektif budaya pesisir itu sendiri.

\section{Pemahaman tentang Budaya Pesisir}

Hubungan antara budaya dan ekologi telah lama menjadi salah satu pusat perhatian para antropolog. Dengan menggunakan pendekatan ekologi, para antropolog berusaha untuk mencari hubungan antara organisme (dalam hal ini manusia) dengan habitat atau lingkungan hidupnya. Pendekatan ini telah melahirkan paling tidak dua bentuk subpendekatan, yaitu pendekatan antropogeografis dan pendekatan posibilis. Pendekatan antropogeografis berusaha untuk meneliti seberapa jauh dan bagaimana caranya kebudayaan manusia itu dibentuk oleh kondisi lingkungannya. Namun demikian subpendekatan ini tidak bisa sepenuhnya dianggap sebagai determinisme lingkungan, karena masih diakui adanya kebudayaan yang bervariasi yang kurang memperlihatkan adanya pengaruh pengaruh yang signifikan dari lingkungan geografis. Sementara pendekatan posibilis

2 Lihat misalnya B.H.M. Vlekke, Nusantara: Sejarah Indonesia (terjemahan Samsudin Berlian) (Jakarta: KPG-Freem Institute, 2008), hlm. 8. memandang lingkungan tidak sebagai sebab, melainkan semata-mata sebagai pembatas dan penyeleksi. Faktor geografis tidak memberi bentuk pada kebudayaan manusia tetapi hanya menetapkan batasbatas bagi bentuk yang mungkin terjadi di suatu lingkungan tertentu pada suatu waktu. ${ }^{3}$

Berdasarkan faktor-faktor ekologi, secara garis besar masyarakat Indonesia lama dapat dibagi dua, yaitu masyarakat pantai dan masyarakat agraris atau pedalaman. Sebelum teknologi berkembang pesat seperti sekarang ini kedua jenis masyarakat tersebut memiliki corak budaya yang memiliki nuansa yang berbeda-beda. Pada tahap awal perkembangannya, kelompok-kelompok sosial yang berupa suku-suku bangsa atau tribe dalam kurun waktu tertentu akhirnya mampu mengembangkan sistem sosial yang mapan (setelah mengalami proses proses perkembangan dalam apa yang disebut zaman batu, perunggu, besi, dan seterusnya). Proses tersebut berkembang terus dengan kedatangan berbagai gelombang pengaruh kebudayaan baru hingga menjelang datangnya pengaruh besar Hindu dan Budha dari India. Dengan kedatangan pengaruh-pengaruh baru tersebut, kebudayaan mereka juga semakin mapan, lengkap, dan bahkan complicated

3 Lihat Clifford Geertz, Involusi Pertanian: Proses Perubahan Ekologi di Indonesia (Jakarta: Bhratara Karya Aksara, 1983), hlm. 1-4. 
baik dalam apa yang oleh C. Kluckhohn disebut sebagai 'tujuh unsur kebudayaan universal' yang mencakup bahasa, sistem teknologi dan alat produksi, sistem mata pencaharian hidup (ekonomi), sistem organisasi sosial, sistem pengetahuan, sistem religi, dan kesenian. ${ }^{4}$

Satu hal yang cukup menarik adalah bahwa pada awalnya, kemunculan kerajaankerajaan kuno di Nusantara ditentukan oleh eksistensi sistem politik pra-Hindu. Hal ini dapat dicontohkan dengan kemunculan kerajaan Kutai sekitar abad ke-5. Pendiri kerajaan Kutai yang bernama Kudungga (sebuah nama non-India) diduga keras merupakan sejenis primus inter pares, seorang kepala suku. Selanjutnya, anaknya yang bernama Mulawarman memegang tampuk pimpinan sebagai raja yang bergaya hidup India. Pada kerajaan maritim, di samping faktor-faktor yang bersumber dari kondisi pra-Hindu, juga ditentukan oleh faktor-faktor geo-strategis dalam kaitannya dengan jaringan perdagangan internasional. Meskipun elemen geo-strategis ini juga penting bagi kerajaan agraris, misalnya banyak pusat kerajaan agraris yang terletak di tepi sungai besar agar memiliki akses dalam perdagangan internasional. ${ }^{5}$

Persoalan lain yang menarik dalam kaitannya dengan signifikasi elemen

\footnotetext{
4 Koentjaraningrat, Pengantar IImu Antropologi (Jakarta: Rineka Cipta, 1990), hlm. 203-204.

5 Lihat Kenneth R. Hall, Maritime Trade and State Development in Early Southeast Asia (Honolulu: University of Hawaii Press, 1985), hlm. 1-10.
}

geografis di kawasan kepulauan seperti Indonesia ini adalah mengapa kalau memang datangnya pengaruh asing melewati pantai, namun dalam tahap awal pengaruh asing ini justru memiliki pengaruh yang mendalam di pedalaman, bukan di pantai. Berdasarkan sumbersumber tertulis justru kerajaan-kerajaan tua yang muncul di Indonesia kebanyakan merupakan kerajaan pedalaman, demikian juga di Cina dan di Timur Dekat Kuno. Pada waktu itu memang kemunculan kerajaan maritim menghadapi kendala teknologis yang tinggi misalnya dalam teknik pembuatan kapal, ilmu pelayaran, ilmu bumi dan sebagainya. Pada saat ini, misalnya, mengapa di kawasan Indonesia Timur di mana secara geografis merupakan kawasan maritim namun dalam banyak hal masyarakatnya hidup sebagai manusia agraris. Hal ini juga berhubungan dengan persoalan kemajuan teknologi. Oleh karena itu, munculnya kerajaan Sriwijaya sebagai kerajaan maritim betul-betul berkembang setelah ada kemajuan di bidang pelayaran. Di Cina misalnya, teknologi pertanian lebih berkembang terlebih dahulu daripada teknologi maritimnya. ${ }^{6}$

$$
\text { Namun demikian pada tahap }
$$
perkembangan selanjutnya, teknologi maritim di Nusantara mengalami perkembangan yang lebih cepat seiring

\footnotetext{
6 Philip D. Curtin, Cross-Cultural Trade in World History (Cambridge: Cambridge University Press, 1984), hlm. 90-108.
} 
dengan interaksi masyarakat Nusantara dengan dunia internasional, terutama dengan India dan Cina. Akibatnya di samping munculnya pusat-pusat perdagangan dan politik di pantai juga akhirnya kerajaan maritim berhasil menghancurkan pusat kekuasaan agraris. Hal ini bisa dilihat dari kehancuran kerajaan Majapahit yang merupakan dinasti agraris dan munculnya kerajaan-kerajaan maritim seperti Demak, Banten, Tuban, Cirebon, dan sebagainya. Meskipun akhirnya kerajaankerajaan ini, kecuali Banten, kembali ditaklukkan oleh kerajaan agraris yaitu Mataram di Jawa Tengah, namun pada saat datang teknologi maritim baru yang dibawa oleh VOC, Mataram yang agraris ini kembali dianeksasi oleh VOC sebagai pemegang hegemoni maritim di Nusantara pada waktu itu. Pada masa menjelang kedatangan bangsa-bangsa Barat, kerajaan-kerajaan maritim mendominasi panggung dunia politik, ekonomi dan budaya kawasan kepulaun Indonesia. Sementara itu keberadaan kerajaan Mataram di pedalaman Jawa Tengah yang bersifat feodalistik sebetulnya hanya merupakan kekecualian belaka.

Pada masyarakat pedalaman, struktur sosial paling tinggi diduduki oleh raja, selanjutnya di bawahnya diduduki oleh para bangsawan. Di bawah itu diduduki oleh golongan petani dan strata yang paling bawah dduduki oleh golongan budak. Pada masyarakat maritim, struktur ini hampir sama, kecuali strata petani di dalam masyarakat agraris diduduki oleh kelompok pedagang, tukang, pengusaha dan sejenisnya. $^{7}$

Mataram sebagai kerajaan pedalaman yang berorientasi agraris sejak awal sangat curiga terhadap sisa-sisa kerajaan pantai setelah runtuhnya kerajaan Demak. Para penguasa pantai yang terdiri dari para bangsawan, ulama, dan pedagang dipandang sebagai ancaman Mataram karena mereka memiliki sumber-sumber kekayaan, jaringan, dan persenjataan yang bisa didatangkan dari negeri seberang. Mataram mulai menaklukkan kawasan pesisir pantai utara Jawa sejak awal abad ke-16 dengan pengecualian Banten. ${ }^{8}$ Mataram menghancurkan hampir semua sumber daya ekonomi negara-negara pesisir yang mengakibatkan eksodus pedagang ke berbagai pelabuhan di Kepulauan Nusantara, seperti Makassar dan

\footnotetext{
7 Peter J.M. Nas, "The Early Indonesian Town: Rise and Decline of the City-State and Its Capital", dalam: Peter J.M. Nas (ed.), The Indonesian City: Studies in Urban Development and Planning (DordrechtHolland: Foris Publication, 1986), hlm. 19-20.

8 Negara pesisir Cirebon tidak dihancurkan, tetapi secara gradual ditransformasikan ke dalam negara feudal oleh Mataram. Kerajaan ini kemudian menjadi orbit Mataram dan berubah menjadi kerajaan pesisir yang feudal. Lihat Singgih Tri Sulistiyono, "Perkembangan pelabuhan Cirebon dan pengaruhnya terhadap kehidupan sosial ekonomi masyarakat kota Cirebon 1859-1930" (Tesis tidak diterbitkan Universitas Gadjah Mada, Yogyakarta, 1994), hlm. 135-139. Lihat juga Sharon Siddique, "Relics of the past? A sociological study of the Sultanates of Cirebon, West Java" (Disertasi tidak diterbitkan pada University of Bieleveld, 1977).
} 
Banjarmasin. ${ }^{9} \quad$ Untuk selanjutnya, pembangunan ekonomi negara-negara pesisir itu menjadi sesuatu yang terlalu mahal dan diperlukan waktu yang lama untuk membangkitkannya kembali. Kotakota perdagangan sepanjang pantai utara Jawa, kecuali Banten, menjadi sangat lemah ketika Belanda mulai memperluas monopoli mereka di kawasan ini pada abad ke-17. Akhirnya kekuatan Barat mampu mengendalikan pusat-pusat perdagangan di kawasan ini. Pada 1619, VOC Belanda merebut kota Jayakarta, diikuti oleh kotakota pelabuhan di sepanjang pantai utara Jawa. Pada pertengahan abad ke-17, Belanda menguasai hampir semua kota-kota pelabuhan timur Jayakarta. Hanya melalui perang yang sengit dan taktik pecah-belah Belanda akhirnya berhasil menguasai Banten pada 1682. Pusat-pusat ekonomi lainnya di luar Jawa mengalami nasib tragis serupa. Sebuah perang yang sengit juga menandai berakhirnya supremasi kerajaan Makasar di Sulawesi Selatan yang dikuasai Belanda pada 1667 melalui Perjanjian Bongaya. VOC akhirnya berhasil memaksakan monopoli di Makassar. Beberapa dekade sebelumnya, VOC telah berhasil mendirikan monopoli atas kepulauan Maluku seperti Ambon dan Ternate di tahun 1605, Banda pada tahun 1609. Selanjutnya VOC akhirnya juga menguasai pusat-pusat budaya, poolitik, dan

9 Lihat Graaf dan Th. Pigeaud, Kerajaan-kerajaan Islam di Indonesia (Jakarta: Grafiti Pers, 1989), hlm. 24-26. ekonomi pesisir di Nusantara seperti Palembang, Lampung, Pontianak, Banjarmasin, dan sebagainya. Malaka, pelabuhan utama Semenanjung Malaysia, telah dikuasai melalui peperangan melawan Portugis pada tahun $1641 .^{10}$

Perseteruan Mataram terhadap daerah pesisir pantai utara Jawa tidak hanya ditunjukkan melalui serentetan penaklukan yang telah dilakukannya terhadap para penguasa pantai yang merupakan keturunan para dinasti lama, tetapi juga direfleksikan dalam sistem pemerintahan dan bahkan juga budaya. Dalam sistem pemerintahan, raja-raja Mataram menempatkan daerah pesisir pantai utara Jawa dalam administrasi tersendiri. Seperti diketahui bahwa raja-raja Mataram membagi-bagi wilayah administrasinya menjadi beberapa kawasan, yaitu Kutagara, Negara Agung, Manca Negara, dan Pesisiran, serta Tanah Sabrang. ${ }^{11}$ Kutagara merupakan wilayah ibukota negara yang di dalamnya terdapat kraton di mana sang raja bertempat tinggal. Negara Agung merupakan wilayah yang mengelilingi Kutagara yang merupakan daerah pertanian dan perkampungan yang merupakan tanah

10 Lihat misalnya D.H. Burger, Sejarah Ekonomis Sosiologis Indonesia I (terjemahan Prajudi Atmosudirdjo) (Jakarta: Pradnja Paramitha, 1962), hlm. 25-30.

${ }^{11}$ Lihat Selosoemardjan, Social Changes in Jogjakarta (Ithaca: Cornell University Press, 1962), hlm. 24. Lihat juga Soemarsaid Moertono, State and Statecraft in Old Java: A Study of the Later Mataram Period, 16th to 19th Century (Ithaca: Cornell University, 1974), hlm. 112. 
lungguh dari para bangsawan dan kerabat raja. Sementara itu Manca Negara merupakan daerah di luar Manca Negara (yang bukan terletak di pesisir pantai utara Jawa) yang dibagi-bagi menjadi kabupaten yang masing-masing dipimpin oleh bupati. Daerah Pesisiran merupakan wilayah kerajaan Mataram yang terletak di kawasan pantai utara Jawa mulai dari Kali Pamali (berbatasan dengan Kesultanan Cirebon) di bagian barat hingga ujung timur pulau Jawa. ${ }^{12}$ Sebagaimana daerah Manca Negara, daerah pesisiran juga dibagi-bagi menjadi kabupaten-kabupaten yang dipimpin oleh seorang bupati. Mereka harus memiliki kesetiaan kepada Sultan Mataram. Sejarah panjang konflik antara Mataram dan daerah pesisiran menyebabkan kontrol Mataram terhadap kawasan ini menjadi sangat ketat.

Pada masa Mataram, konsep pesisir bukan hanya menyangkut wilayah geoadministratif semata-mata. Konsep pesisir atau pesisiran juga sudah memiliki beban konotatif yang bersifat kultural. Masyarakat dan budaya pesisir memiliki konotasi budaya yang berbeda dengan budaya pedalaman yang merupakan pusat atau center budaya Jawa yang terletak di kraton. Sementara itu budaya pesisir ditempatkan sebagai budaya yang marginal.

Dikotomi semacam ini barangkali cocok dengan konseptualisasi yang digagas oleh

\footnotetext{
12 Lihat Denys Lombard, Nusa Jawa: Silang Budaya I (Batas-batas Pembaratan) (terjemahan Winarsih Partaningrat Arifin, Rahayu S. Hidayat, Nini Hidayat Yusuf) (Jakarta: Gramedia, 2008), hlm. 37.
}

Redfield mengenai the great tradition (tradisi besar) yang berpusat di kraton dan the little tradition (tradisi kecil) yang menyebar di kalangan masyarakat yang jauh dari kraton..$^{13}$ Marginalisasi masyarakat dan budaya pesisir ini dapat dilihat dari ungkapan di Jawa yang merepresentasikan kedudukan masyarakat pesisir, khususnya nelayan, yaitu 'cerak watu adoh ratu' (dekat dengan batu, jauh dari raja). ${ }^{14}$

Zaman Mataram merupakan sebuah periode pada saat masyarakat dan budaya Pesisir mengalami tekanan baik melalui serangkaian penaklukan militer maupun marginalisasi kultural. Padahal sesungguhnya budaya pesisir sudah jauh lebih lama berkembang daripada Mataram Islam. Kerajaan Sriwijaya pada abad ke-7 yang kemudian disusul oleh kerajaan Melayu dan selanjutnya oleh kerajaankerajaan Islam seperti Samudera Pasai, Demak, Cirebon, Banten, Banjarmasin, Ternate, Makassar, dan sebagainya merupakan pusat-pusat politik dan budaya pesisir. Beberapa peninggalan patung yang bercorak Hindu ditemukan di berbagai tempaut di daerah pesisir Jawa seperti Banten, Pekalongan, Tuban, Jepara, Lasem, dan sebagainya. ${ }^{15}$ Bahkan penelitian terakhir terhadap situs peninggalan kapal di

\footnotetext{
13 Robert Redfield, Masyarakat Petani dan Kebudayaan (Jakarta: Grafiti Pers, 1985), hlm. 57-61.

14 Lihat Pujo Semedi, Close to the Stone, Far from the Throne: The Story of A Javanese Fishing Community 1820s-1990s (Yogyakart: Benang Merah, 2003), hlm. 301.

15 Lombard, Nusa Jawa, hlm. 37.
} 
Lasem disimpulkan bahwa peninggalan kapal itu berasal dari masa kerajaan Sriwijaya sekitar abad ke-7 Masehi. Sementara itu Surabaya sudah berkembang sebagai pelabuhan penting di pesisir utara Jawa pada abad ke-14.

Meskipun kerajaan-kerajaan pesisir sudah muncul sejak zaman Sriwijaya pada abad ke-7 Masehi namun perkembangannya mengalami pasang-surut. Namun demikian menurut Lombard, kebangkitan kota-kota pesisir baru terjadi abad ke-15 dan ke-16 dengan bermukimnya komunitas Cina, awal islamisasi, dan berdirinya Kesultanan Demak. ${ }^{16}$ Dalam proses Islamisasi di kawasan pesisir pantai utara Jawa peran tokoh-tokoh Islam yang terkenal dengan sebutan wali songo merupakan representasi gairah perkembangan elemen budaya pesisir pada waktu itu. Demikian juga kedatangan ekspedisi maritim Laksamana Cheng Ho yang beragama Islam telah menciptakan legenda dan cerita rakyat yang tersebar di kawasan-kawasan pesisir di belahan Nusantara bagian barat. Di semarang misalnya, kenangan terhadap sang Laksamana ini terus terpelihara hingga saat ini yang terwujud dengan kelenteng Sam Po Kong. ${ }^{17}$ Rupanya perkembangan

${ }^{16} \mathrm{lbid} ., \mathrm{hlm} .37$.

17 Tentang perkembangan kelenteng Sam Po Kong dalam kaitannya dengan identitas masyarakat Cina lihat Singgih Tri Sulistiyono, "Contesting the Symbol: Zheng He, Sam Po Kong Temple and the Evolution of Chinese Identity in Semarang", makalah dipresentasikan pada The First International Conference on Zheng $\mathrm{He}$ and Afro-Asian World kota-kota pesisir itulah yang memungkinkan terjadinya jaringan pelayaran dan perdagangan di antara mereka. Perhubungan laut menjadi sangat signifikan dalam proses pertukaran itu karena jalur darat memang hampir tidak memiliki fungsi yang signifikan dalam konteks pertukaran dan persebaran budaya di Nusantara. Dalam hubungan itulah Lombard mengatakan bahwa apa yang disebut sebagai 'kebudayaan pesisir' merupakan kebudayaan yang mencerminkan unsur Islam yang kuat, penggunaan bahasa Melayu yang sangat luas serta kehadiran unsur-unsur budaya Cina. ${ }^{18}$

Vickers lebih senang menggunakan konsep 'peradaban psisir' daripada 'budaya pesisir'. Menurutnya konsep budaya dengan berbagai bentuk artistik dan struktur maknanya yang mencirikan kelompokkelompok tertentu yang unik. Sementara itu konsep peradaban lebih bersifat 'cair' sehingga dapat menerobos batas-batas definisi religius, etnis, ras, dan status namun dapat memberikan kesadaran tentang sebuah dunia budaya dan tatanan yang merangkul berbagai elemen. ${ }^{19}$ Barangkali di sinilah konsep 'bhinneka tunggal ika' dapat dipahami secara kontekstual. Masyarakat

(Melaka: International Zheng He Society, 5-8 Juli 2010).

18 Lombard, Nusa Jawa Silang Budaya I, hlm. 39.

19 Adrian Vickers, Peradaban Pesisir: Menuju Sejarah Budaya Asia Tenggara (Den Pasar: Pustaka Larasan-Udayana University Press, 2009), hlm. 5. 
Nusantara yang berperadaban pesisir pada waktu itu sudah memiliki kesadaran peradaban yang sama dan memiliki simbolsimbol budaya yang diakui bersama namun pada saat yang sama di antara mereka masih tetap memiliki perbedaan-perbedaan budaya, etnisitas, ras, dan sebagainya. Perbedaan-perbedaan tersebut masih tetap diakui keberadaannya dalam kerangka kesadaran peradaban yang sama, yaitu sebuah peradaban pesisir. Vickers menujuk cerita Panji dan berbagai jenis narasi teks yang dikenal sebagai sastra pesisir sebagai salah satu elemen peradaban Pesisir. Melalui teks-teks itu, berbagai norma dan batas-batas budaya bersama disebarkan, dimodifikasi, dan diciptakan kembali. Sebagai dokumen kultural, teks-teks cerita Panji memberikan orientasi standar yang ideal masyarakat ningrat di kawasan peradaban Pesisir, misalnya tentang busana, etiket, gaya hidup, pertunjukan, ritual, dan sebagainya. $^{20}$ Dengan demikian sikap pengakuan, bahkan penegasan, terhadap perbedaan dan kesediaan untuk menghormati serta hidup berdampingan merupakan ciri yang inheren dari peradaban Pesisir. Hal yang senada juga diungkapkan oleh Thohir bahwa sifat-sifat umum masyarakat pesisir adalah terbuka,

20 Vickers, ibid., hlm. 8. Hal serupa juga dideskripsikan oleh Reid. Lihat Anthony Reid, Southeast Asia in the Age of Commerce, Vol. I: The Lands below the Winds (New Haven-London: Yale University Press, 1988). lugas, dan egaliter. ${ }^{21}$ Dalam hal ini barangkali budaya pedalaman yang feodalistik lebih fanatik dan memiliki etnosentrisme yang tinggi. Mataram misalnya, memandang orang-orang dari luar Jawa sebagai orang 'sabrang' yang di dalam pertunjukan wayang diberi cap sebagai orang-orang yang memiliki sikap yang kasar, tidak memiliki sopan-santun, dan tidak njawani.

Menurut penelitian Vickers, ceritacerita Panji sebagai salah satu elemen kental dalam peradaban Pesisir telah menyebar di berbagai wilayah di Jawa, Sumatra, Bali, Lombok, Sulawesi Selatan, bahkan sampai di Semenanjung Melayu, Thailand, dan Burma.22 Bahkan Hildred Geertz mencatat spektrum kesamaan peradaban Pesisir di Nusantara ini lebih detail. Dia mengatakan adanya kesamaan kultural di berbagai wilayah pesisir di Nusantara, yaitu Semenanjung Melayu (terutama berpusat di Malaka), kepulauan Riau-Lingga, Palembang, Jambi, Aceh, Banjarmasin, pa ntai utara Jawa, Madura, Sulawesi Selatan, Gorontalo, Sumbawa, sejumlah kawasan di Nusatenggara Timur, beberapa bagian Maluku terutama Ternate, Tidore, Bacan, dan Goram. ${ }^{23}$ Perkembangan peradaban Pesisir ini tampaknya erat kaitannya dengan

${ }^{21}$ Mudjahirin Thohir, Orang Islam Jawa Pesisiran (Semarang: Fasindo Press, 2005), hlm. 40.

22 Vickers, Peradaban Pesisir, hlm. 8.

${ }^{23}$ Hildred Geertz, "Indonesia Cultures and Communities", dalam; Ruth McVey (ed.), Indonesia (New Haven: Southeast Asia Studies, Yale University, 1967), hlm. 10. 
perkembangan pelayaran dan perdagangan serta proses Islamisasi yang berkembang pesat pada abad ke-16. Jatuh-bangunnya kerajaan-kerajaan pesisir selama abad ke15 hingga abad ke-17 justru menimbulkan pergerakan sentrifugal yang disusul dengan semakin tersebarnya peradaban Pesisir ke berbagai kawasan di Nusantara.

\section{Multikulturalisme dalam Peradaban}

\section{Pesisir}

Bagian ini akan menunjukkan ciri-ciri multikulturalisme dalam peradaban pesisir. Hal itu dapat dilihat dari aspek jaringan global dalam pelayaran dan perdagangan serta sifat kosmopolitanisme masyarakat pesisir.

\section{Jaringan Global}

Asia Tenggara unumnya dan Nusantara khususnya memiliki posisi geografis yang sangat strategis yaitu terletak dalam jalur perdagangan internasional lewat laut (Jalan Sutera) antara dua negara adidaya pada waktu itu yaitu India dan Cina. Suatu hal yang bukan merupakan kebetulan jika orang-orang Asia Tenggara pada waktu itu bisa memanfaatkan potensi ini untuk melibatkan diri secara aktif dalam perdagangan itu. Bukti-bukti historis menunjukkan bahwa sejak abad ke-2 masehi sudah ada hubungan dagang antara kawasan Asia Tenggara dan India. Selanjutnya sejak abad ke-5 juga sudah mulai ada utusan diplomatik ke negeri Tiongkok. Tentu saja hubungan itu bermula dari proses perdagangan. Komoditi perdagangan yang diperdagangkan pada waktu itu adalah lada, cengkih, pala, kayu cendana, beras, kain, dan sebagainya. Adapun etnik yang terlibat dalam kegiatan itu misalnya: Champa, Jawa, Melayu, Ambon, Ternate, Bugis, Makassar, Banjar, India, Arab, dan sebagainya. ${ }^{24}$

Munculnya kerajaan Sriwijaya sebagai kerajaan maritim hampir bisa dipastikan berkaitan erat dengan perdagangan internasional antara India dan Cina dan perdagangan regional di antara daerahdaerah di Nusantara, antara daerah di Nusantara dan kawasan Asia Tenggara dan antara daerah di Nusantara dengan Cina. Dengan kemampuan untuk mengelola aktivitas perdagangan yang berlalu-lalang di kawasan Nusantara bagian barat, pada puncak perkembangannya Sriwijaya mampu mengontrol kawasan Selat Malaka dan Selat Sunda. Seperti diketahu bahwa jika suatu negara hidup dari perdagangan berarti penguasanya harus menguasai jalurjalur perdagangan dan pelabuhanpelabuhan tempat barang-barang dagangan itu ditimbun untuk diperdagangkan. Tindakan yang demikian ini jelas memerlukan kontrol langsung dari penguasa. Kesetiaan dan kontrol langsung merupakan persoalan yang sangat penting dalam negara maritim. Oleh karena itu Sriwijaya mengembangkan politik yang berorientasi pada kontrol atas sumber- 
sumber perdagangan. ${ }^{25}$ Mungkin Sriwijaya sendiri tidak begitu strategis letaknya karena agak jauh dari Selat Malaka, namun dengan kekuatan armadanya ia menguasai daerah-daerah yang potensial untuk menjadi pesaingnya dan dapat mengontrol jalur perdagangan yang berada di bawah kekuasaannya dari perompakan dan kemungkinan agresi dari negara lain. Dengan cara ini ia menyalurkan perdagangan ke pelabuhan-pelabuhan yang dikuasainya. Dengan begitu Sriwijaya telah menjadi sumber perdagangan yang penting antara Cina dan India. Suatu yang menarik adalah bahwa untuk kepentingan perdagangannya, Sriwijaya rela mengakui Cina sebagai negara besar yang berhak untuk diberi upeti. Dengan cara demikian Sriwijaya akan merasa aman akan bahaya ekspansi militer Cina yang sudah meramah ke Vietnam dan Funan. Selain itu kapalkapal Sriwijaya juga akan mendapatkan perlakuan yang lebih baik di pelabuhanpelabuhan di Cina. ${ }^{26}$

\section{Dengan kemampuannya} mengamankan alur pelayaran di kawasan selat Malaka, maka Sriwijaya yang berpusat di Palembang ini pada abad XIII mampu menguasai titik-titik simpul perdagangan dan sekaligus membangun jaringan

25 Pierre-Yves Manguin, 'Palembang and Sriwijaya: An Early Malay Harbour-City Rediscovered', JMBRAS 1 (66) (1993) 33.

${ }^{26}$ O.W. Wolters, Early Indonesia Commerce: A Study of the Origins of Srivijaya (Ithaca, New York: Cornell University Press, 1967), hlm. 152. pelayaran dan perdagangan di antara kawasan pesisir itu, antara lain P'eng-feng (Pahang), Teng-ya-nung (Trengganu), LingYa-ssu-chia (Langkasuka), Chi-lan-tan (Kelantan), Fo-lo-an (Kuala Berang), Tanma-ling (Tambralingga, Ligor), Chia-lo-si (Grahi, Teluk Brandon,), dan Sin-t'o (Sunda).27 Ketika orang-orang Cina sudah mulai ramai datang sendiri ke pelabuhanpelabuhan Sriwijaya, maka hubungan antara kawasan pesisir di Nusantara juga semakin erat terhubungkan dengan Asia Timur.

Berkembangnya kerajaan Sriwijaya di Sumatra sejalan dengan berkembangnya kerajaan-kerajaan di Jawa Tengah dan Jawa Timur mulai dari kerajaan Mataram, Medang, Kediri, Singasari hingga Majapahit. Persaingan, konflik, dan akomidasi antara Sriwijaya dengan kerajaan-kerajaan di Jawa itu juga memperluas spektrum jaringan antara pusat-pusat ekonomi, politik, dan budaya di Nusantara.

Jika pada masa Singasari persekutuan kerajaan-kerajaan di Nusantara hendak dirintis dengan jalan yang relatif damai karena menghadapi ekspansi Mongol, maka pada masa Majapahit persatuan hendak ditegakkan dengan cara-cara yang lebih keras dengan kekuatan militer. Jika upaya Kertanegara untuk merintis 'persekutuan suci' Nusantara didasarkan pada bahaya ekspansi luar, maka Majapahit melakukan

\footnotetext{
${ }^{27}$ Lihat juga R. Braddell, 'An Introduction to the Study of Ancient Times in the Malay Peninsula and the Straits of Malacca', JMBRAS 14 (1936) 1-71.
} 
hal yang sama dengan didorong terutama oleh ambisi-ambisi internal yang melihat kelumpuhan politik pusat-pusat dagang di Nusantara sebagai motivasi untuk menempatkan mereka di bawah panji-panji kebesaran dan kesatuan Majapahit. Setelah Sriwijaya lemah secara internal, Majapahit dapat 'mewarisi' sebagian besar wilayah kekuasaannya.

Perpecahan internal yang dialami Majapahit pada akhir abad XIV mendorong daerah-daerah yang dikuasainya menjadi daerah yang berdiri sendiri. Salah satu bekas daerah keuasaan Majapahit adalah Malaka yang justru terletak di jantung 'Melayu Circle'. Munculnya Malaka pada akhir abad XIV sebagai pusat perdagangan Melayu dan Nusantara ini bertepatan dengan yang sangat strategis. Di satu pihak Majapahit sudah lemah dan di pihak lain ancaman dari kerajaan tentangganya, Ayutthaya, yang berusaha melakukan ekspansi ke selatan. Namun demikian ancaman Ayutthaya ini dapat ditangkal oleh Malaka dengan menjalin hubungan diplomatic dengan Cina yang pada waktu sedang aktif melakukan patroli dan ekspedisi ke kawasan Asia Tenggara dengan di bawah Laksamana Cheng-Ho.

Selain itu, munculnya Malaka bersamaan dengan memuncaknya perdagangan Islam yang menguasai jalurjalur perdagangan dari Timur Tengah hingga kawasan Asia Tenggara. Dengan menggunakan Islam sebagai agama, para penguasa Malaka dapat menarik dukungan dan jaringan perdagangan Islam berpusat di Malaka. Kota pelabuhan ini merupakan transito untuk komoditi dari kawasan Nusantara untuk diperdagangkan baik ke 'Dunia Timur' maupun 'Dunia Barat'. Melalui pelayaran dan perdagangan ini pula peradaban pesisir menjadi identitas bersama meskipun perbedaan-perbedaan di antara mereka masih dipertahankan namun bida hidup secara berdampingan

\section{Kosmopolitanisme Masyarakat dan} Peradaban Pesisir

Sudah sejak jaman prasejarah Nusantara dihuni oleh berbagai bangsa dan kelompok etnik. Sudah barang tentu percampuran di antara kelompok sosial tersebut bukan merupakan sesuatu yang mustahil. Ketika hubungan-hubungan antara kelompok sosial ini menjadi semakin intensif sejalan dengan perkembangan kegiatan perdagangan yang semakin ramai. Pusat-pusat perdagangan di Nusantara menjadi titik temu di antara berbagai jenis kelompok manusia dengan kebudayaan mereka masing-masing. Belum lagi hubungan politik dan penaklukan militer di antara kekuatan-kekuatan politik yang ada juga menjadi salah satu saluran interaksi di antara berbagai kelompok masyarakat di Nusantara. Dengan demikian sudah sejak lama orang-orang Nusantara (khususnya masyarakat pesisir) bertemu dan mengenal berbagai jenis bangsa dari luar mulai dari bangsa-bangsa dari kawasan Timur Tengah 
hingga Jepang dan Pasifik. Dalam soal ini bahkan mungkin bangsa-bangsa Eropa sendiri belum banyak mengenal jenis-jenis bangsa dan kelompok etnik sekompleks orang-orang Nusantara telah mengenal pluralitas dalam dirinya sendiri dan orangorang luar yang datang di kawasan ini. Untuk mengetahui sedikit gambaran mengenai tingkat kosmopolitanitas dan multikulturalitas Nusantara dalam sejarah maka perlu digambarkan paling tidak dua hal yaitu masyarakat kota-kota dan migrasi.

\section{a. Kehidupan Kota-kota}

Sejak masa pra-sejarah, Nusantara telah dihuni oleh berbagai ras dan kelompok etnis. Ketika komunikasi antara kelompokkelompok etnik dan ras menjadi semakin intensif sejalan dengan perkembangan perdagangan dan pelayaran sebagai media interaksi sosial. Dalam hal ini kota-kota dagang dan pelabuhan berfungsi sebagai titik pertemuan berbagai ras dan kelompok etnis dengan latar belakang sosial dan budaya mereka masing-masing. Selain itu, hubungan-hubungan politik dan bahkan penaklukan militer juga menjadi media penting dari interaksi antara masyarakat di Nusantara. Oleh karena itu orang-orang Nusantara telah terbiasa bertemu dan berkenalan dengan berbagai ras dan kelompok etnis lain seperti orang-orang dari Cina, Jepang, kepulauan Pasifik, Timur Tengah, Asia Selatan, Asia Tenggara, dan sebagainya. Orang-orang Nusantara terutama yang tinggal di kota-kota pelabuhan sudah terbiasa berinteraksi dengan kelompok-kelompok etnis asing . Mereka terbiasa hidup dalam situasi pluralistik dan kosmopolitan.

Sejak abad ke-15 dan ke-16 terjadi peningkatan peran sektor kelautan dalam bidang kekuasaan politik dan perkembangan ekonomi. Hampir semua kekuatan politik di wilayah ini bergantung pada sektor pelayaran dan perdagangan. Keberadaan kerajaan pertanian seperti Mataram di Jawa adalah sebuah pengecualian. Pada abad ke-15, peran kekuatan politik di pedalaman banyak digantikan oleh kerajaan-kerajaan maritim. Fenomena ini terjadi hampir di semua wilayah di Nusantara. ${ }^{28}$

Periode ini juga menyaksikan bahwa kawasan Nusantara barangkali merupakan salah satu kawasan yang paling urban di dunia. Hal ini dapat dihitung dari proporsi yang signifikan dari jumlah penduduk yang hidup di kota-kota dibandingkan dengan di pedalaman. Jika seseorang berbicara tentang orang-orang Nusantara pada waktu itu berarti berbicara tentang kota, pedagang, pelaut, nelayan, seniman, pengrajin, dan kelompok sosial lain dari penduduk kota. Oleh sebab itu periode itu bukanlah merupakan periode masyarakat desa. Demikian juga apa yang disebut sebagai Melayu atau mungkin tradisi

28 Anthony Reid, Dari Ekspansi hingga Krisis: Jaringan Perdagangan Global Asia Tenggara 1450-1680 (Jakarta: Yayasan Obor Indonesia, 1999), hlm. 8283. 
austronesia sebetulnya bukan merupakan tradisi pertanian tetapi pelayaran, perdagangan, dan kehidupan perkotaan sebagai ditunjukkan oleh Kesultanan Malaka dan berbagai kota pesisir di Nusantara. Reid memprediksi bahwa jumlah penduduk kotakota pelabuhan penting di Asia Tenggara (termasuk Nusantara) pada periode itu sekitar 50.000 - 100.000 orang. Pada saat yang sama, kota-kota Eropa yang memiliki penduduk lebih dari 100.000 hanya Paris dan Napoli. Hanya beberapa kota memiliki populasi lebih dari 40.000 orang. ${ }^{29}$

Hal ini tidak mengherankan jika Tome Pires, pelaut Portugis pertama yang mengunjungi Asia Tenggara pada waktu itu mengatakan bahwa kota Malaka sebagai kota yang "tak tertandingi di dunia '. Pires menyebut berbagai kelompok pedagang internasional di Malaka:

'Moors from Cairo, Mecca, Aden, Abyssinians, men of Kilwa, Malindi, Ormuz, Parsees, Rumes, Turks, Turkomans, Christian Armenians, Gujaratees, men of Chaul, Dabhol, Goa, of the kingdom of Deccan, Malabars and Klings, merchants from Orissa, Ceylon, Bengal, Arakan, Pegu, Siamese, men of Kedah, Malays, men of Pahang, Patani, Cambodia, Champa, Cochin China,

29 Deskripsi yang leboh detail mengenai jumlah penduduk di berbagai kota utama di Asia Tenggara dapat dilihat pada Reid, Dari Ekspansi, hlm. 82-100.
Chinese, Lequeos, men of Brunei, Lucoes, men of Tamjompura, Laue, Banka, Linga, Moluccas, Banda, Bima, Timor, Madura, Java, Sunda, Palembang, Jambi, Tongkal, Indragiri, Kappatta, Menangkabau, Siak, Arqua (Arcat?), Aru, Bata, country of the Tomjano, Pase, Pedir, Maldives... The above-mentioned peoples come to Malacca with junks, pangajavas and ships... Finally, in the port of Malacca very often eighty-four languages have been found spoken, every one distinct, as the inhabitants of Malacca affirm'.30

Pires membandingkan Malaka dengan kota-kota Eropa seperti Lisbon, Venetia, dan kota-kota lain yang pernah dikunjungi di Eropa. Gambaran Pires menunjukkan betapa kota Malaka memiliki sifat kosmopolitan dan sekaligus juga menunjukkan betapa penting peran pelayaran dan perdagangan maritim di Nusantara. Meskipun memiliki skala yang lebih kecil berbagai kota pesisir di Nusantara juga merupakan tempat pertemuang berbagai jenis kelompok etnis dan ras. Di berbagai kota pesisir dapat dengan mudah dijumpai perkampungan

30 Armando Cortesao (Penerjemah dan editor), The Suma Oriental of Tome Pires, An Account of the East from the Red Sea to Japan, Written in Malacca and India in 1512-1515 (New Delhi and Madras: Asian Educational Services, 1990), hlm. 118-119 \& 268. 
Bugis, Makassar, banjar, Jawa, Madura, Melayu, Koja, Keling, Arab, dan sebagainya yang semuanya itu mencerminkan multikulturalisme masyarakat dan peradaban Pesisir. Multikulturalitas kota esisir juga bisa dilihat pada perkembangan kota Makassar. Hingga akhir abad XV Makassar belum merupakan pusat perdagangan di Indonesia Timur. ${ }^{31}$ Pelabuhan ini hanya merupakan rendezvous bagi pedagang Jawa yang sedang dalam perjalanan lalu-lalang ke kepulauan Maluku dan sekitarnya untuk menacari rempahrempah. Perubahan besar segera terjadi pada abad XVI ketika terjadi eksodus pedagang muslim dari Malaka yang direbut oleh Portugis pada tahun 1511 menuju ke Makassar. Seperti diketahui bahwa telah terjadi perseteruan yang sengit antara Portugis dan pedagang muslim di Asia ketika Portugis mengibarkan Perang Salib di lautan semenjak penjelajahan mereka ke

31 Hall mencatat bahwa sebelum datangnya bangsabangsa Eropa, Makassar belum merupakan pusat jaringan perdagangan. Pada waktu itu ada beberapa jaringan dagang atau zone perdagangan di Asia Tenggara dan sekitarnya yaitu: Jaringan Teluk Benggala (mencakup pesisir India Selatan, Srilangka, Birma, pesisir utara dan barat Sumatra), Jaringan Selat Malaka, Jaringan Teluk Tonkin (mencakup: pantai timur Semenanjung Malaya, Thailand, dan Vietnam Selatan), Jaringan Laut Sulu (meliputi pesisir barat Luzon, Mindoro, Cebu, Mindanao dan sekiatrnya), dan Jaringan Laut Jawa (yang mencakup Jawa, Kalimantan, Sumatra Selatan, Bali, Nusa Tenggara, Sulawesi Selatan, bahkan hingga Maluku. Lihat Kenneth R. Hall, Maritime Trade and State Development in Early Southeast Asia (Honolulu: University of Hawaii Press, 1985), hlm. 24. dunia timur. ${ }^{32}$ Menetapnya para pedagang muslim di Makassar merupakan fondasi bagi terbentuknya sebuah pelabuhan entrepot baru di Nusantara bagian timur. Setelah berkembang sebagai pelabuhan besar, kota ini terus dibanjiri para pedagang asing yang sebagian dari mereka menetap di kota ini.

Sebagai masyarakat yang bersifat pluralistik (karena terdiri dari banyak kelompok suku bangsa, ras dan agama), sistem politik di Makassar cukup tebuka dan khas dalam peradaban Pesisir dalam mengakomodasikan berbagai kepentingan untuk kemajuan perdagangannya. ${ }^{33}$ Keterbukaan ini juga bisa dilihat dari kesediaan penguasa setempat untuk menerima apa yang dalam masyarakat modern disebut sebagai 'modernisasi'. Mereka burusaha untuk mendapatkan kemajuan dari teknologi dan hal-hal baru yang dipandang bermanfaat dari orangorang asing yang datang di Makassar. Dua tokoh terkenal yang memiliki sikap progresif seperti ini adalah Karaeng Matoaya dan Pattingaloang. Mereka tidak malu-malu untuk mengambil apa saja yang dipandang berguna untuk kemajuan mereka dari pengetahuan para pengunjung

32 K.N. Chauduri, Trade and Civilization in Indian Ocean: An Economic History from the Rise of Islam to 1750 (Cambridge: Cambridge University Press, 1989), hlm. 15.

33 Tentang pluralisme masyarakat Makassar pada waktu itu lihat Anthony Reid, 'Pluralism and Progress in Seventeenth-century Makassar', Bijdragen tot de Taal-, Land- en Volkenkunde 156 (3) (2000), 433449. 
Makassar termasuk teknik pembuatan kapal Eropa dan Cina, pembuatan dan penggunaan peta nautis yang waktu itu sudah lazim digunakan pelaut Eropa, mencetak uang logam, dan sebagainya. ${ }^{34}$ Masa pemerintahan Matoaya (1593-1610) juga merupakan periode ketika Makassar mengadopsi Islam. Dari satu sisi, Islamisasi di Makassar merupakan bagian dari politik pembangunan perdagangan yang sangat genius, sebab sebagian besar perdagangan di Nusantara waktu itu berada di tangan orang-orang Islam. Sudah barang tentu pengadopsian unsur budaya asing bukan hanya untuk kepentingan mode dan imitasi tetapi juga untuk memenuhi kebutuhan lokal. Bugis dan Makassar menciptakan sendiri alfabet untuk membuat bahasa mereka sebagai simbul yang mudah dipahami oleh semua kelompok pedagang baik untuk kepentingan hukum maupun bisnis. Mereka memiliki alfabet yang relatif sama meskipun bahasanya sangat berbeda. 35

\section{b. Migrasi}

Migrasi dan mobilitas sosial merupakan salah satu ciri penting dalam masyarakat pesisir. Selama abad XVI-XVII terjadi perubahan-perubahan demografik

${ }^{34}$ Makassar dan Aceh merupakan dua kerajaan prakolonial Indonesia yang memiliki uang emas mereka sendiri.

35 Lihat Curtin, Cross-Cultural Trade, hlm. 162. Lihat juga Anthony Reid, 'A Great Seventeenth Century Indonesia Family: Matoaya and Pattingalloang of Makassar', Majalah IImu-IImu Sosial Indonesia 8 (1981), 12-23. dengan datangnya banyak bangsa asing di Nusantara seperti orang-orang Cina, India, Arab, Persia, dan bangsa-bangsa Barat. Orang-orang Cina dan India sudah memiliki tradisi untuk bermigrasi ke Nusantara, namun pada periode ini menunjukkan intensitas yang lebih besar. Sementara itu kedatangan bangsa Eropa secara massal merupakan gejala baru bangi orang-orang Nusantara. Sudah barang tentu migrasi ini merupakan saluran interaksi lintas budaya yang juga merupakan ciri masyarakat dan peradaban Pesisir. Interaksi ini membawa perubahan-perubahan dan respon pada masyarakat lokal baik seperti adaptasi, konflik, relokasi, akulturasi, amalgamasi, dan lain-lain. Hal ini tercermin dari perpaduan dalam sistem pemerintahan, ekonomi, bangunan fisik, munculnya kelompok sosial baru, dan perkembangan di bidang ilmu pengetahuan dan teknologi (perkapalan, persenjataan) dan lain-lain.

Migrasi tidak hanya terjadi dalam kaitannya dengan bangsa-bangsa asing yang datang di Nusantara, tetapi juga migrasi lokal di antara kelompok etnik di Nusantara. Perkembangan aktivitas pelayaran dan perdagangan memungkinkan terjadinya migrasi berbagai kelompok-kelompok etnis di kawasan Nusantara. Bahkan, kelompok etnik yang sat ini dipandang bukan sebagai masyarakat perantau pun pada waktu itu (terutama pendidik pesisir) juga merupakan masyarakat perantau. Dalam hal ini peranan perantau Jawa dapat dilihat di Malaka 
sebagai pusat perdagangan terbesar di Nusantara menjelang kedatangan bangsabangsa Barat. Schrieke mengatakan bahwa perdagangan di Nusantara pada waktu itu 'largerly in Javanese hands'.36 Sementara itu Meilink-Roelofsz menyatakan bahwa Malaka yang merupakan pasar internasional terbesar di Nusantara di mana 84 bahasa digunakan setiap hari didominasi oleh dua dua kelompok pedagang paling kaya dan paling berkuasa yaitu orang-orang India dan orang Jawa. ${ }^{37}$ Sementara itu Hall juga mengatakan: ${ }^{38}$

'... the trade was in Javanese hands, and by the beginning of the 16th century they formed the most important element in Malacca's population. The army was the Javanese; most of its shipwrights were Javanese; and the great Javanese aristocratic families who ran the trade between Eastern Indonesia and Malacca were represented there.'

Dalam hubungan ini, tidak hanya orang Jawa yang bermigrasi ke daerah di

36 B. Schrieke, Indonesia Sociological Studies (Bandung: Van Hoeve, 1957), hlm. 64.

37 M.A.P. Meilink-Roelofsz, Asian Trade and European Influence in the Indonesian Archipelago between 1500 and about 1630 (The Hague: Nijhoff, 1962), hlm. 37, 55.

38 D.G.E. Hall, A History of Southeast Asia (London: Macmillan, 1966), hlm. 199. pusat-pusat perdagangan dan pelayaran, tetapi juga kelompok etnis lain. Di kota Makassar pada masa prakolonial misalnya, dapat ditemukan dengan mudah orang Jawa, Banjar, Madura, Melayu, Bali, dan sebagainya. Selain itu, kelompok-kelompok etnis dari kepulauan lain juga dapat dengan mudah ditemukan di sebagian besar kotakota pelabuhan di sepanjang pantura Jawa seperti Banten, Cirebon, Demak, Tuban, Gresik, dan Surabaya. Di kota-kota tersebut, pemukiman Bugis, Madura, Melayu, dan Makassar bukan merupakan hal yang aneh. Migrasi internal sebenarnya merupakan salah satu dasar yang paling penting untuk menciptakan pemahaman budaya di antara kelompok-kelompok sosial di Nusantara.

\section{Catatan Akhir}

Dari uraian di atas dapat diambil beberapa catatan penting:

1. Bahwa paradigma multikulturalisme yang menekankan sikap dialog, toleransi, dan kesediaan untuk koeksistensi damai dalam keberagaman sesui dengan salah satu pilar kebangsaan Indonesia, yaitu Bhinneka Tungal Ika. Hal itu sesuai dengan relitas bangsa Indonesia yang bersifat plural sehingga membutuhkan paradigma yang mampu membingkai keberagaman.

2. Masyarakat dan peradaban pesisir memiliki perspektif multikulturalisme yang berakar dari latar belakang historisnya.

Perspektif 
multikulturalisme peradaban pesisir dapat dilihat dari sifat kosmopolitanitas dan pluralitas masyarakat dan budayanya. Masyarakat pesisir sejak lama telah memiliki jaringan nteraksi global yang sangat luas memlaui berbagai media seperti pelayaran, perdagangan, migrasi, dan sebagainya. Masyarakat dan budaya pesisir merupakan bagian yang inheren dari budaya dunia. Sifat kosmopolitanitas ini yang menyebabkan peradaban pesisir ini memiliki sifat terbuka, demokratis, toleran, dialog, kemauan unutk berkoeksistensi damai. Sementara itu sifat pluralitas masyarakat dan budaya pesisir juga tidak dapat dilepaskan dari akan historis. Sejak zaman kuno masyarakat pesisir merupakan masyarakat yang plural sebagai akibat dari kegiatan pelayaran, perdagangan, hubungan-hubungan politik dan budaya, diaspora, dan sebagainya. Hal ini mengondisikan masyarakat pesisir sebagai masyarakat plural. Pengalaman hidup bersama dalam perbedaan namun memiliki kepentingan yang sama telah melahirkan mentalitas multikulturalisme yang merupakan ciri inheren peradaban pesisir. Peradaban pesisir merupakan peradaban yang dinamis dan selalu terbuka bagi perubahan. Dalam perjalanan sejarah selalu terjadi proses pembentukan dan pembentukan kembali identitas masyarakat yang bergantung kepada dinamika internal dan pengaruh eksternal. 